\title{
A Study on Urban Furniture: Nicosia Old City
}

\author{
By Mine Kuset Bolkaner, Selda İnançoğlu, Buket Asilsoy ${ }^{1}$, Ph.D
}

\begin{abstract}
Urban furniture can be defined as aesthetics and comfort elements that reflect the identity of a city and enable the urban space to become livable. Urban furniture is an important element of the city in order to improve the quality of urban life, to create a comfortable and reliable environment and to meet the needs of the users in the best way. For designing these elements, the social, economic, cultural and architectural structure of the city should be considered and evaluated. It is important to adapt the urban furniture to the urban texture and to the cultural structure achieving an urban identity, in order to ensure the survival and sustainability of the historical environments. In this study, a study was carried out in the context of urban furniture in Nicosia Walled City, which has many architectural cultures with its historical texture. In this context, firstly the concept of urban identity and urban furniture was explained and then, information about urban furniture was given in historical circles with urban furniture samples from different countries. As a field study, a main axis was determined and the streets and squares on this axis were discussed. These areas have been explored starting from Kyrenia Gate in North Nicosia; İnönü Square, Girne Street, Atatürk Square, Arasta Square, Lokmacı Barricade and on the south side Ledra Street and Eleftherias Square. In this context, the existing furniture in the North and South were determined and evaluated in terms of urban identity accordingly. As a result, it can be suggested that the existing street furniture equipments, especially on the north side, do not have any characteristic to emphasize the urban identity. According to the findings, it was determined that the urban furniture in the streets and squares on the north side is generally older and neglected, and does not provide a unity with the environment, whereas on the south side, these elements on the street and square are relatively new, functional and environmentally compatible.
\end{abstract}

Key words: urban furniture, historical environment, urban identity, Nicosia Old City

\section{Introduction}

Today, the importance of cities for individuals is increasing day by day. Especially after the Industrial Revolution, the growth of cities has gained momentum (Beyaz \& Asilsoy, 2019; Marquez-Ballesteros et al., 2019). However, this rapid growth is mostly not comprehensive and has brought many environmental and social problems related to urbanization (Kamruzzaman, Deilami, \& Yigitcanlar, 2018). As a result of this rapid and unplanned urbanization process, dangerous issues such as deforestation, environmental pollution, depletion of natural resources, loss of habitat areas, and destruction of plant and animal species have emerged (Asilsoy et al., 2017). Thus, in the 1970s, issues such as urban design, urban ecology, urban identity, quality of urban life, cultural heritage conservation, public open and green areas, began to be accepted around the world, as the major elements of sustainable urbanization, especially in developed 
countries. In other words, in order to solve the emerging problems, sustainability of urban environments has become a key issue in the context of current urban development policies (Arbolino, Simone, Carlucci, Yigitcanlar \& Ioppolo, 2018; Asilsoy, 2012; Asilsoy \& Oktay, 2018).

Nicosia, the capital of both the northern and southern parts of Cyprus, a Mediterranean island, faced various urban planning and design problems, mostly related with rapid urban development tendencies. All these problems are an obstacle for the city to have an identifiable identity. For example, it can be argued that public open spaces in the city are not planned and well-defined in order to create walkable, pedestrian-friendly and livable urban environments. However, the existence of well-defined high-quality public spaces is one of the important topics of sustainable urbanization (Ewing, Hajrasouliha, Neckerman, Purciel Hill, \& Greene, 2015). Therefore during the last few decades, the civic importance of public spaces and the role they play in the improvement of the quality of life of citizens have been two of the areas of inquiry for researchers in the field of urbanism and on the agenda of city authorities in developed countries (Conteh \& Oktay, 2016). Historical urban environments, as cultural heritage sites, are important elements in providing identity to a city by supporting sustainability, especially in cultural and social dimensions. Therefore, both the preservation of historical urban textures and the development of urban spaces in these urban environments are among the highlights of this framework.

Nicosia Old City, which is divided into two as a north and south by the Green Line passing through it, is a historical environment with a well-established architectural and cultural heritage that should be a priority in the city's sustainable planning and design agenda. Walled City, which incorporates the historical urban texture of Nicosia, is an open-air museum that exhibits the past periods of the island with many works of different cultures within the history of the city (Turkan \& Özburak, 2018).

In this context within this study, firstly literature review about urban identity and urban furniture concepts were made. Afterwards, Nicosia Old City, as the research context, was examined. Then, research method and findings were evaluated respectively. Finally, conclusions and recommendations were shared.

\section{Literature Review}

\subsection{Urban Identity}

The cities are the places that are constantly changing since the first day they started to form. The social structure of the cities and the economy and traditions of the period have an important role on this evolution process. In almost every period, the cities are also places that shape the relations between individuals, no matter their characteristics.

Cities do not only consist of structures that meet people's housing needs; as a result of collective life, many common requirements occur. Due to the progress of development, cultural structure or managerial investments, many built-up areas or spaces emerge in cities that meet these needs and whose qualitative and quantitative levels vary over time and within the space. In this context, the structured and unstructured areas constituting the texture of the cities form the 'urban space' (Salama \& Azzali, 2015; Faragallah, 2018). These urban spaces are the whole of the places where functions such as sheltering, 
working, entertainment, resting and transportation are carried out in relation to human life (Bulut et al., 2008).

According to Bayrakç1 (1989), a city is the whole of the systems that are in relation to each other, within the fields of different assets and are in operation. These systems can be individuals' lifestyle, social structure, public, private or semi-private spaces, the nature of the city and all other elements of the city. All these features are the indicators of identity regarding the city. In this sense, urban identity is a manifestation of all physical and cultural elements from the past to the future. According to Oktay (2002), urban identity is one of the main targets for creating a good environment. Citizens should feel that part of the environment, individually and collectively, is their own and that they have responsibilities to this particular environment. At the urban level, the environment should encourage citizens to express themselves and to participate.

Those who define urban identity often state that cities have their own internal dynamics, just like a human. The urban designer Çöl (1998) stated that the urban identity was a meaningful continuous development influencing the urban image developed by the cultural, socio-economic, historical and formal elements of the city; this urban image also achieves sustainability as a concept and involves experiences of the individuals living in the city from the past to the future as an integrated process. At this point it can be argued that urban furniture, as one of the founding elements of the physical urban environment, is one of the determinants of urban identity. The emergence of this situation, as being a significant feature of the urban identity, arises from the physical location of urban furniture. Such that urban furniture equipments are located at the spaces where all urban relations occur, in the presence of citizens living in the city. Therefore, urban furniture has an important place in the formation of a thourough city identity (Bayramoğlu and Özdemir, 2011).

\subsection{Urban Furniture}

Urban furniture is often referred to as fixed service equipments and structures for open space functions, where the user is uncertain. Urban furniture, together with the concept of the city, consists of items intended to meet the growing and increasing needs of users as a result of a specific process (Bingöl, 2017).

In urban design, the layouts of elements that are visually arranged with a harmony, create particularly eye-catching and memorable images. Urban furniture, as a remarkable feature of the city image, plays an active role in urban design as a whole, whether in terms of functional or aesthetic dynamics. Integrating urban furniture with the architectural features of a place is significant for the individuals who use it. When designed and assembled harmoniously, the seating units, trash cans, signs, lighting units and similar furniture create a positive visual impact on the urban area. Well-designed urban furniture reflecting or completing a city can be the symbol of the city in the meantime (Ghorab and Caymaz, 2015).

Urban landscape elements that support and strengthen basic activities for streets, squares, roads, avenues etc. and facilitate social life gaining the appreciation of society via achieving shelter, protection, siege, transportation, consultation, lighting, communication, description as a symbol of comfort and environmental quality are defined as urban furniture (Bayramoğlu and Özdemir, 2011). Urban furniture are 
diversified depending on the characteristics of countries and cities. These elements have a high prominent role in facilitating urban identity and community life (Aksu, 2012).

According to Bayrakç1 (1991), these urban equipments are elements that facilitate the personal and social life of citizens within the urban fabric, provide communication among individuals, have different quantities and qualities that give functional and aesthetical meaning to the spaces. Therefore, they are of great importance not only for functional purposes, but also because they have invigorating effects on urban landscape. The list of the urban furniture elements and their design criteria for the urban squares are displayed in Table 1.

Table 1. Urban furniture equipments and their design criteria (Bayramoğlu and Özdemir, 2011)

\begin{tabular}{|c|c|}
\hline $\begin{array}{l}\text { Urban furniture } \\
\text { elements }\end{array}$ & Design criteria \\
\hline Restraints & $\begin{array}{l}\text { It is used as walls, screens, iron or wood railings or green fences as } \\
\text { prevention elements. } \\
\text { The prevention should be applied in accordance with the environment. } \\
\text { In addition to aesthetic and functional principles, psychological effects } \\
\text { should be taken into consideration. }\end{array}$ \\
\hline Seating elements & $\begin{array}{l}\text { The size, material and design of seating elements directly affect the } \\
\text { physical comfort of the users. } \\
\text { The length of the seating elements should be } 60 \mathrm{~cm} \text { per person. } \\
\text { Seating elements must not restrict the movement and should be } \\
\text { positioned } 60 \mathrm{~cm} \text { inside the road. }\end{array}$ \\
\hline Trash cans & $\begin{array}{l}\text { The trash cans should be placed at the points where they are most } \\
\text { needed. } \\
\text { The best locations for trash cans are the points near to the urban } \\
\text { furniture such as benches and telephone booths and also the places that are } \\
\text { used extensively by users, such as the entrances of buildings. }\end{array}$ \\
\hline Signs & $\begin{array}{l}\text { The signs should be well visible. } \\
\text { Unnecessary information should be avoided. } \\
\text { A-10 years) }\end{array}$ \\
\hline Sculptures & $\begin{array}{l}\text { Most often, sculptures serve as complementary elements within the } \\
\text { composition. } \\
\text { They may also achieve a symbolic but impressive meaning for the urban } \\
\text { identity. }\end{array}$ \\
\hline Water features & $\begin{array}{l}\text { Water features can be used in various ways such as waterfalls, water walls, } \\
\text { water channels, pools and fountains in urban open spaces. }\end{array}$ \\
\hline $\begin{array}{l}\text { Shading } \\
\text { elements }\end{array}$ & $\begin{array}{l}\text { Shading elements provide functions such as shade, protection from rain, } \\
\text { rest, passive recreation and they achieve 3rd dimension to the space }\end{array}$ \\
\hline $\begin{array}{l}\text { Lighting } \\
\text { elements }\end{array}$ & $\begin{array}{l}\text { The lighting elements should be designed according to the dynamics such } \\
\text { as aesthetic compatibility with the city character, efficiency and comfort. } \\
\text { Lighting elements should be chosen as resistant to various weather } \\
\text { conditions for a long time. } \\
\text { Physical properties such as strength and visual properties such as color } \\
\text { or harmony with the landscape should be considered for the lighting } \\
\text { elemenets. }\end{array}$ \\
\hline
\end{tabular}




\subsection{Urban furniture in historic quartes}

The remaining settlements of past times and the ruins of that periods constitute the historical environments. Many significant values related to the lifestyles and social, cultural, economic, architectural characteristics of the past periods are hidden within the historical circles. Historical circles are the environments that affect the social relations between human beings in a positive way and thus increase the sense of unity and togetherness among individuals (Ahunbay, 1996). The events that are witnessed in historical circles directly or indirectly affect the relations between the individuals experiencing the city, the urban design and the usage of the urban space eventually.

These circles are the most remarkable signs of the creativity of the societies that have lived in the past with many styles and rich arrangements they have, their admirable beautiful views, their pleasant curvy and astonishing streets and their attentive workmanship. However rapidly changing construction techniques, current trends and changing traditions lead to changes in these environments. Therefore, in addition to the designs reflecting the historical cities, it is necessary to design the urban furniture that provides the cultural continuity and increase the visual diversity and that are also compatible with the living conditions required by today (Ertaş, 2017). In other words, urban furniture can be an efficient tool to sustain and enrich all these valuable characterisctics of the historic sites that can enable the urban environments more identical and liveable.

In urban design, the layouts of elements that create a visual integrity provide eye-catching and memorable images. Urban furniture as an element defining the image and identity of the city plays an active role in urban design as a whole, either in terms of its functions or its aesthetic values. It is very important to integrate urban furniture with the architectural features of the space and to be able to make the users accept the urban furniture. When harmoniously designed and assembled together, seating units, trash cans, signs, lighting elements and similar furniture equipments create a positive visual impact on a urban space. Well-designed urban furniture that reflects or completes an urban environment becomes a symbol, reflecting the identity of that city over time. Examples of these urban furniture in historic surroundings include red telephone booths in London and lighting elements in Notre Dame Bridge in Paris (Ghorab and Caymaz, 2015). 

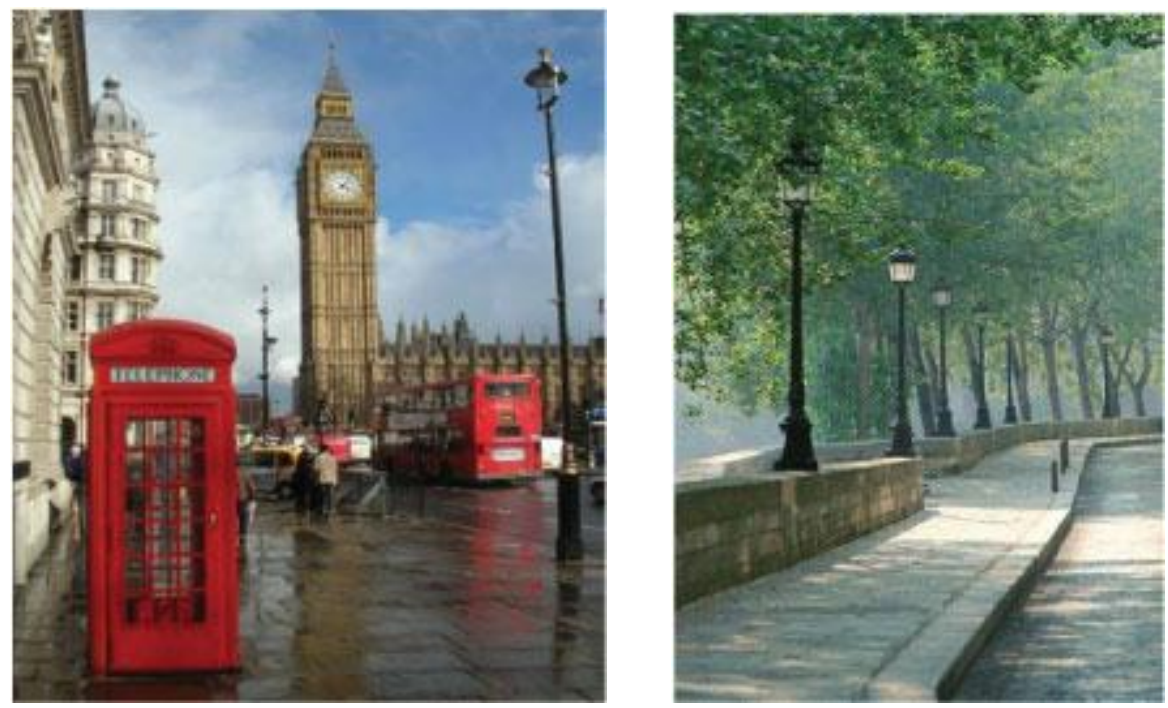

Figure 1: Telephone booths in London and lighting elements in Paris Notre Dame Bridge Reference: (Ghorab and Caymaz, 2015).

\subsection{Urban furniture in different countries}

Urban furniture, which plays an instrumental role in strengthening the identity of urban spaces within various uses, has the ability to make the space convenient and a focus point. This diversity depends not only on their use but also on their location and portability (Şatır and Korkmaz, 2005).

Figure 2 and Figure 3 display examples from Trafalgar Square (London) and Trocadéro Square (Paris) located in the historic city centers. Large water elements found in two squares attract user attention. The pavings, which are used as other urban furniture elements, are designed in harmony with the surrounding buildings in the square.

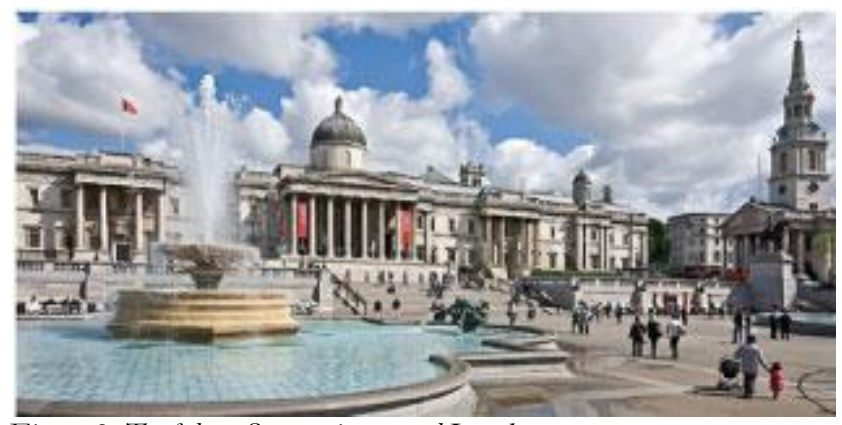

Figure 2: Trafalgar Square in central London

Reference: http:// www.reidsengland.com/places/London/see/trafalgar-square/ 


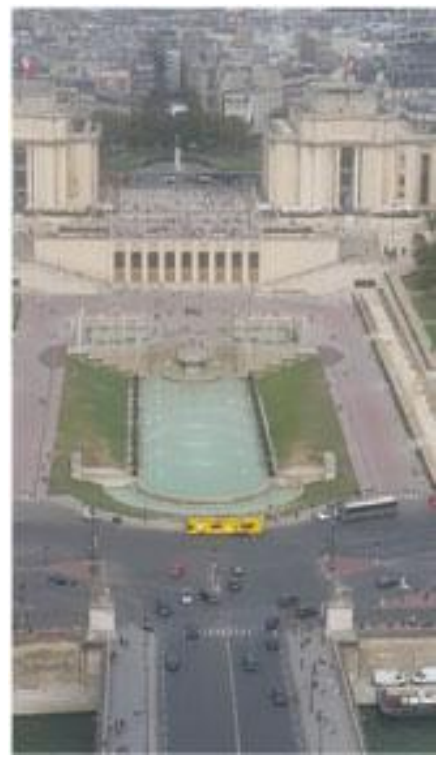

Figure 3: Trocadéro Square in Paris city center (Kuset Bolkaner, 2018)

Urban furniture should be designed according to certain standards in terms of anthropometric measurements; attention should be paid to functional and aesthetic features (line, size, form, color, texture etc.); the design must be unique and easy to understand the usage (Ghorab and Caymaz, 2015).

It can be argued that the form determines function, dimensions and material. The shape of an object arises from the functions associated with it, and from the service which it is expected to provide. Additionally the form plays an important role in determining the character of a space. Figure 4 and Figure 5 display examples of seating and lighting elements in disparate forms.
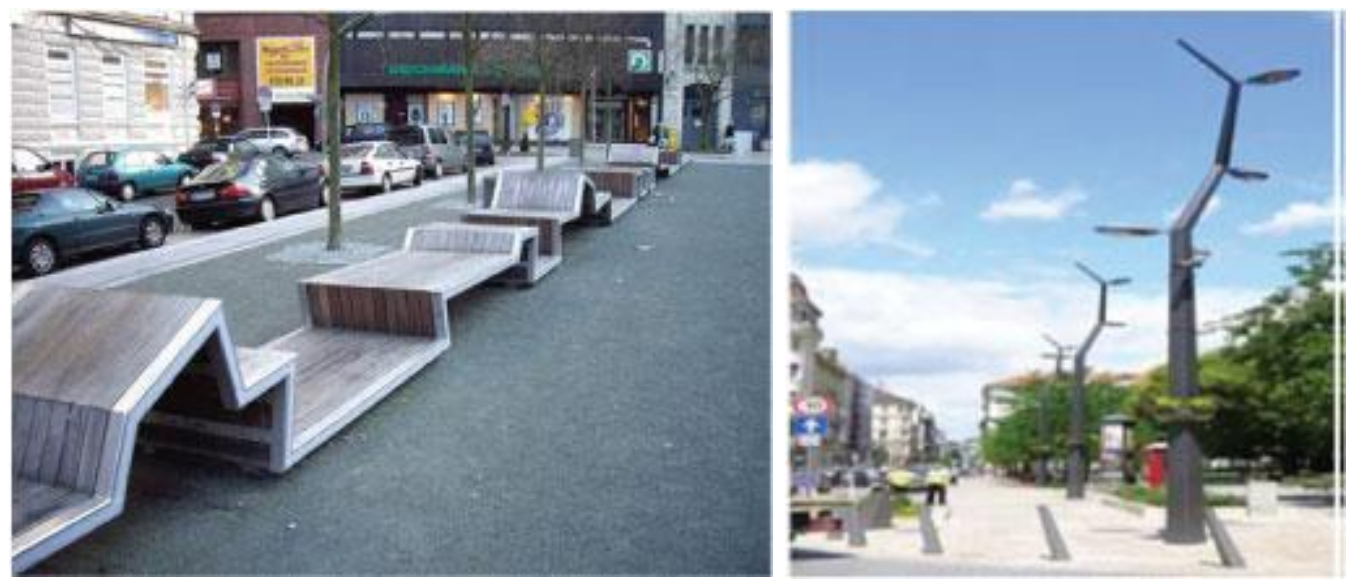

Figure 4: Seating elements used in different forms and textures as urban furniture in Hamburg (Germany) Reference: bttps: / www flickr.com/photos/tlraum/2166398682/in/faves-copacetic/

Figure 5: Lighting elements designed aesthetically as urban furniture in Budapest (Hungary) 
Figures 6 displays the Charles Bridge and Figure 7 displays the square in the city center of Prague (Czech Republic), which is a historical environment and completely pedestrianized. Floor coverings, lighting elements, top cover elements and limiting elements are noteworthy.

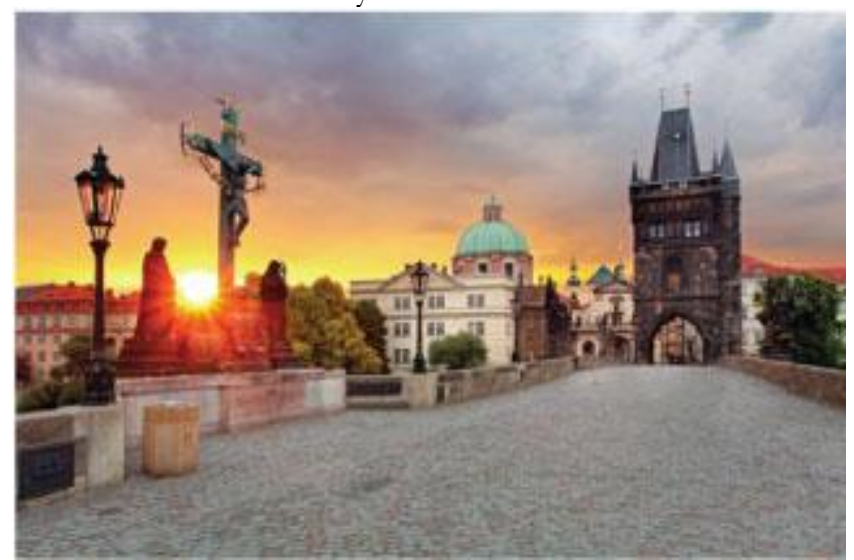

Figure 6: Lighting, sculpture, trash can and paving used as urban furniture elements in Charles Bridge (Prague) Reference: http:/ / www.praguego.com/ about/
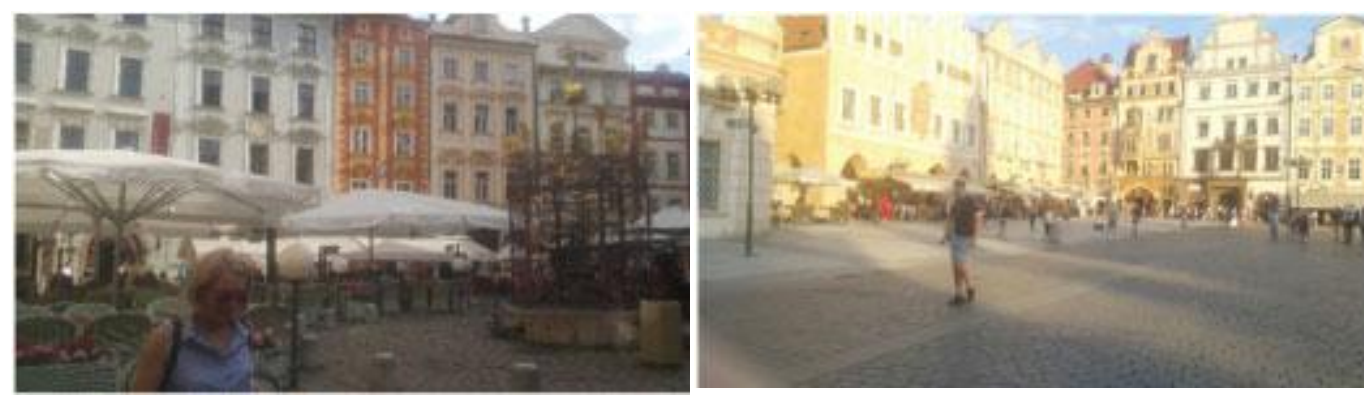

Figure 7: Elements used as urban furniture elements in the square at the center of Prague Reference: Kuset Bolkaner, 2018

Figure 8 displays the Historic City Center (Ciutat Vella) where a rehabilitation project was applied. The seating elements are located in the historic city center of Barcelona and the square also contains various forms of limiting elements. 

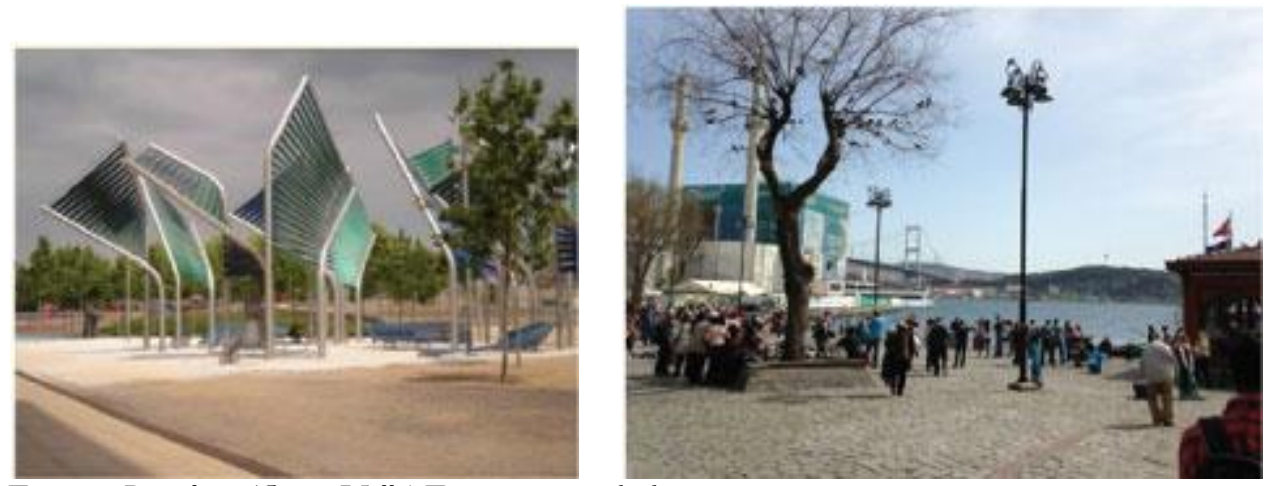

Figure 8: Barcelona (Ciutat Vella) Equipments in the historic city center

Reference:https:/ / acikders.ankara.edu.tr/pluginfile.php/11884/mod_resource/content/1/7.2.\%20Hafta\%20K $\%$ C3\%BClt\%C3\%BCrel\%20Kimli $\%$ C4\%9Fi\%20Yans\%C4\%B1tan $\% 20 D o n a t \% C 4 \% B 1$ lar.pdf

Examples of Taksim and Ortaköy in İstanbul, Turkey is shown in Figure 9. Here, different floor coverings, lighting elements, seating elements and the sculpture, which have become the symbol of the square, stand out as the urban furniture.
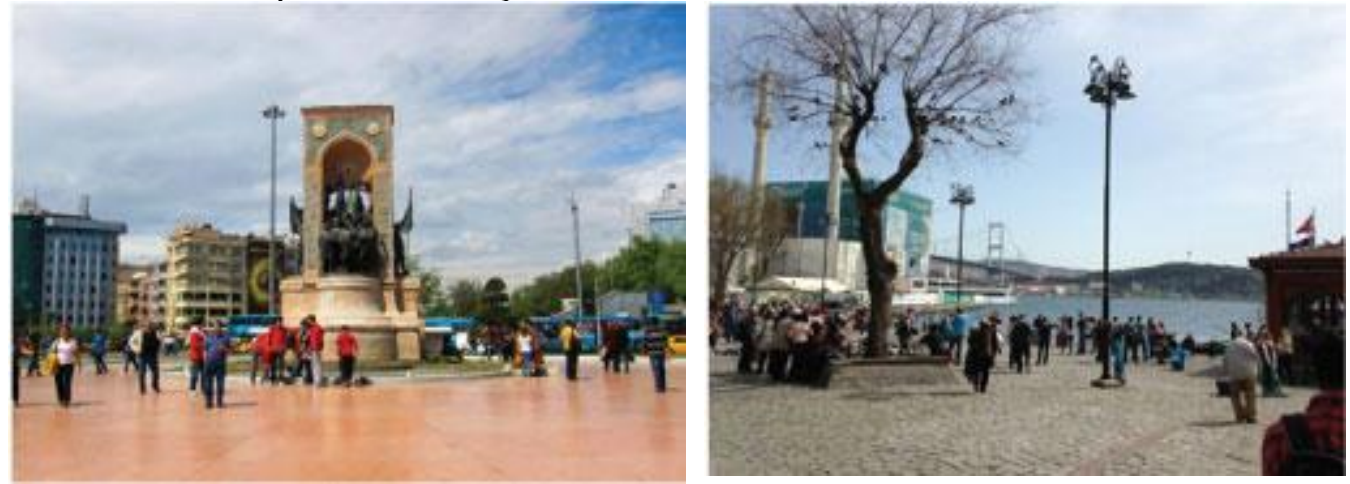

Figure 9: Istanbul Taksim Square and Ortakëy Square (Turkey)

Reference: bttp:/ / wnw.destination360.com / europe/turkey/ taksim-square

bttps:/ / tr.foursquare.com/ v/ ortak\%C3\%B6y-meydan\%C4\%B1/4bfa0fd74a67c928b3d627of

\section{Research Method}

\subsection{Nicosia Old City as the Research Context}

The city of Nicosia is located at the intersection of the main road network connecting Famagusta, Kyrenia and Güzelyurt. It is the most populous and capital city of Cyprus as the industry, trade and transportation center (Bolkaner, 2018). Nicosia is an old city located in the central part of Cyprus and in the central part of the Mesaria Plain (Gurkan, 1996).

The island has been under the control of many empires and kingdoms for many years due to its geographical location. These empires and kingdoms had a significant impact on the physical changes of the city of Nicosia. The city has a history dating back to approximately 7000-3000 BC (Altan, 2016). 


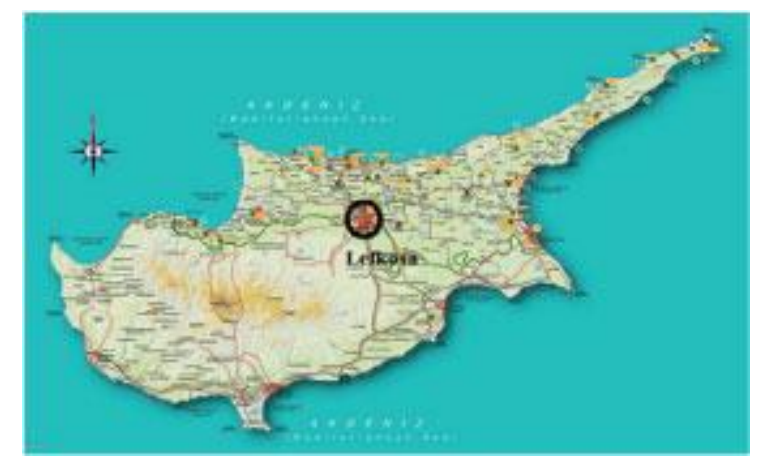

Figure 10: Map of Cyprus

Reference:https://kibris.com.tr/images/haritalar/kibris_karayollari_haritasi.jpg

Nicosia Old City as the study area, having a rich historical and cultural background, has survived to the present day and contains many important works in terms of cultural identity. It is a valuable part of the city, in the heart of the capital Nicosia. It is also an important tourist destination as it is shaped by the cultural accumulation of different societies and as a bridge between the past and the future.

The city of Nicosia is the only divided capital in the world. Since the Green Line has divided the Old City District into two, the study area is considered as North and South Old City. Streets as the main artery of Nicosia Old City and the squares within these streets are designated as study area. Starting from Kyrenia Gate; Inönü Square, Girne Street, Atatürk Square, Arasta Square, Lokmac1 Barricade and on the South, Ledra Street and Eleftherias Square are examined within the study.
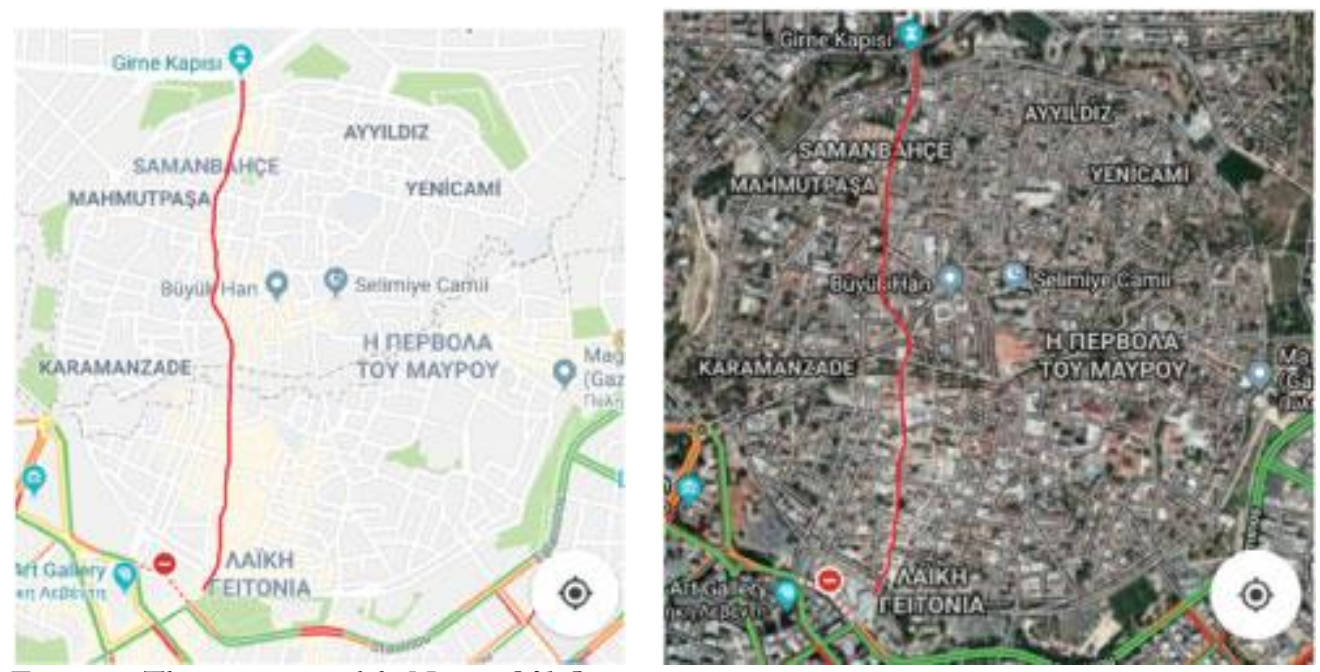

Figure 11: The main artery of the Nicosia Old City

Reference: https:// www.google.com/maps/place/Nicosia, +Cyprus 


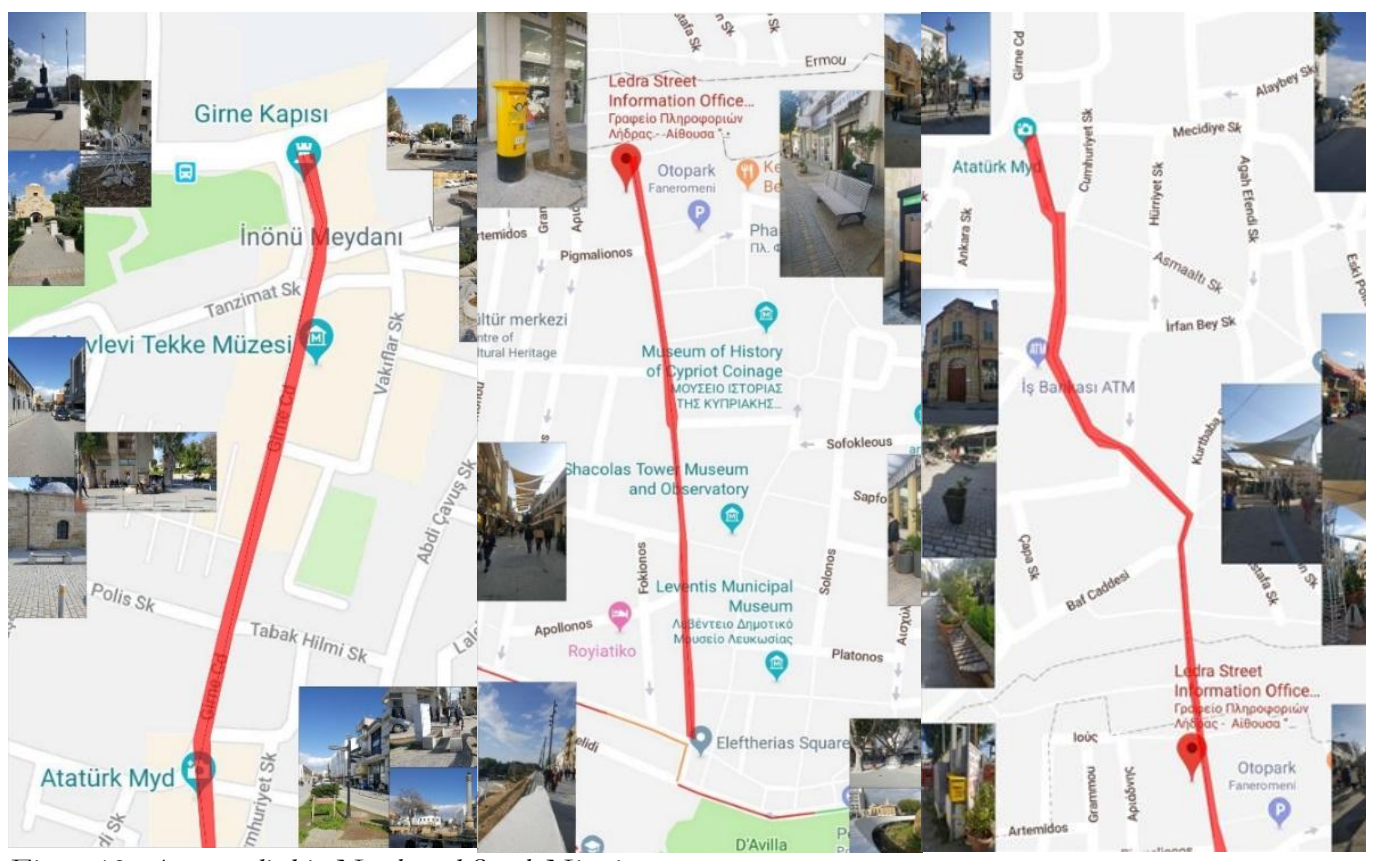

Figure 12: Axes studied in North and South Nicosia

Reference:https:// www.google.com/maps/place/Nicosia, +Cyprus

\section{4. Method}

\subsection{Measurement and Data Collection}

Existing Urban Furniture: Urban furniture, which is classified according to its functions, classified as follows (Ertaş, 2017), has been investigated within the study area.

1. Pavings (concrete, stone, wood, asphalt, brick etc.)

2. Seating units (benches, chairs, group seating elements)

3. Lighting elements (road illuminators, field illuminators)

4. Signs (routers, locators, information boards)

5. Barriers (limiters, deterrents, pedestrian barriers, traffic barriers)

6. Water features (ornamental pools, fountains)

7. Shelters (canopy, pergolas)

8. Trash cans

9. Flower pots

10. Other elements (sale units, infrastructure services, artistic objects-sculptures, playground elements, telephone booths, mail boxes, etc.)

The field study was completed in seven days between 05.01.2019 and 12.01.2019. The study was conducted within the scope of the measurement and data collection regarding the existing urban furniture of the streets and squares on the main artery of the Nicosia Old City. In this context firstly the north side (starting from Kyrenia Gate; Inönü Square, Kyrenia Street, Atatürk Square, Arasta Square, Lokmac1 Barricade) was investigated and then data collection was made on the south side (Ledra Street and Eleftherias Square). 


\section{Results}

\subsection{Analysis of the existing urban furniture at the North Nicosia Old City}

It was determined that the lighting elements in Inönü Square did not have a specific effect regarding the urban identity and did not not show any unity with the surrounding buildings and the environment. In addition, it has been observed that the seating elements are inadequate and old fashioned, the paving is poor and the trash cans do no conform to the environment (See Table 2).

Table 2. İnönü Square's existing urban furniture

\begin{tabular}{|l|l|}
\hline Inönü Square existing urban furniture & \\
\hline Pavings & \\
\hline Seating units & \\
\hline Lighting elements & \\
\hline Signs & \\
\hline Brash & \\
\hline Shelters & - \\
\hline
\end{tabular}

When looking at the Kyrenia Gate and Kyrenia Street, it was observed that there was a uniformity regarding the use of the lighting elements along the street while the surrounding environment was not compatible. In addition there was a lack of trash cans and signs along the street and the existing ones were with different materials and types. Although the seating elements and flower pots were used harmoniously around the 
Kyrenia Gate as the entrance of the street, it was observed that they were not used along the street (See Table 3).

Table 3. Street furniture at Kyrenia Street

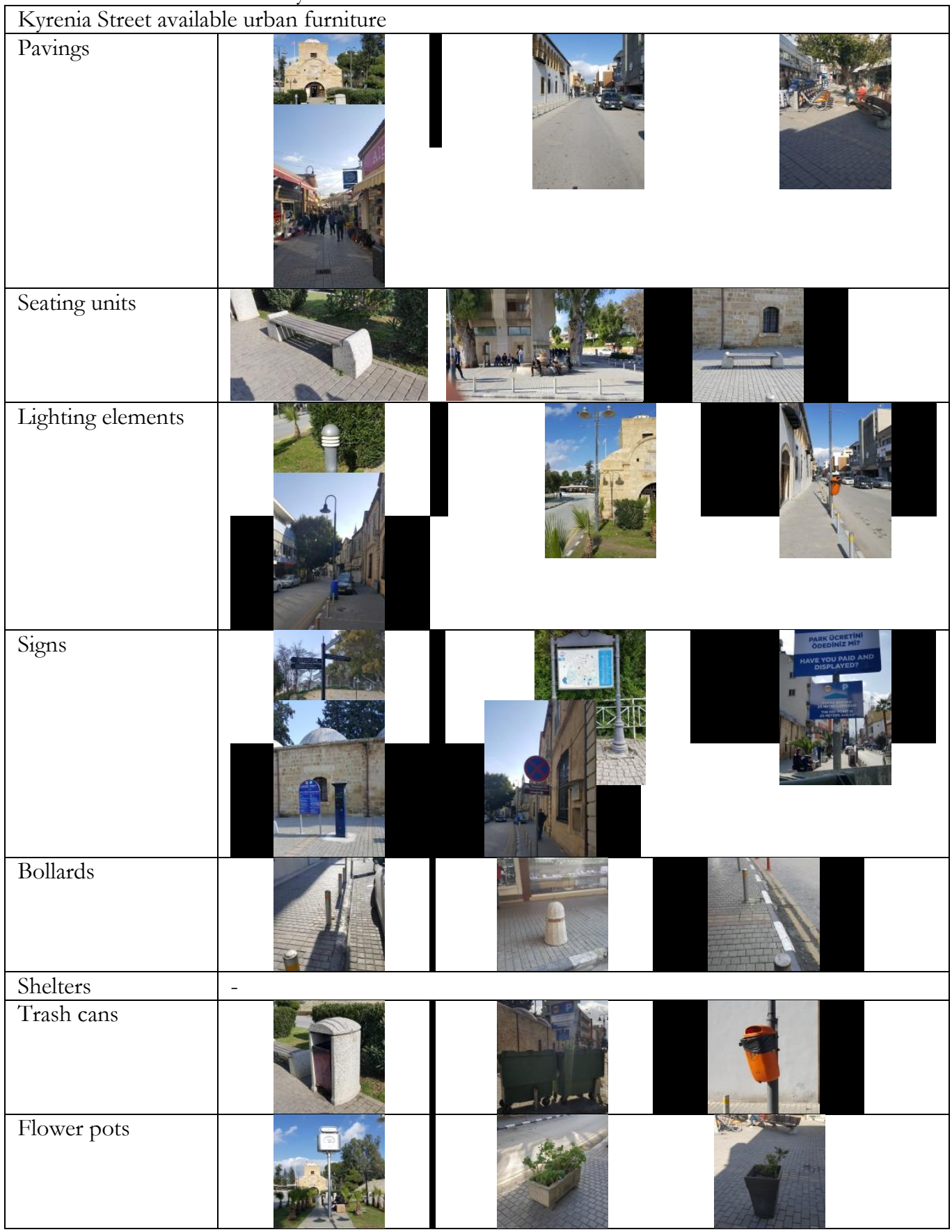




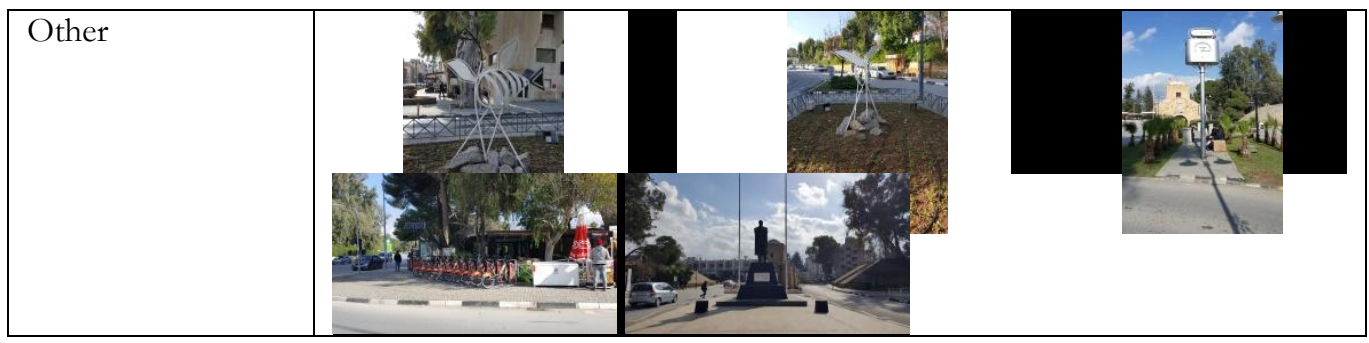

The urban furniture used in Atatürk square was old fashioned, not functional and insufficient in quantity. It was also found that the seating elements and lighting elements were incompatible with the identity of the surrounding environment. In addition, signs and billboards used in the square do not conform to the historical buildings. On the other hand, cover elements used in the square allow users to sit comfortably (Table 4).

Table 4. Atatürk Square's existing urban furniture

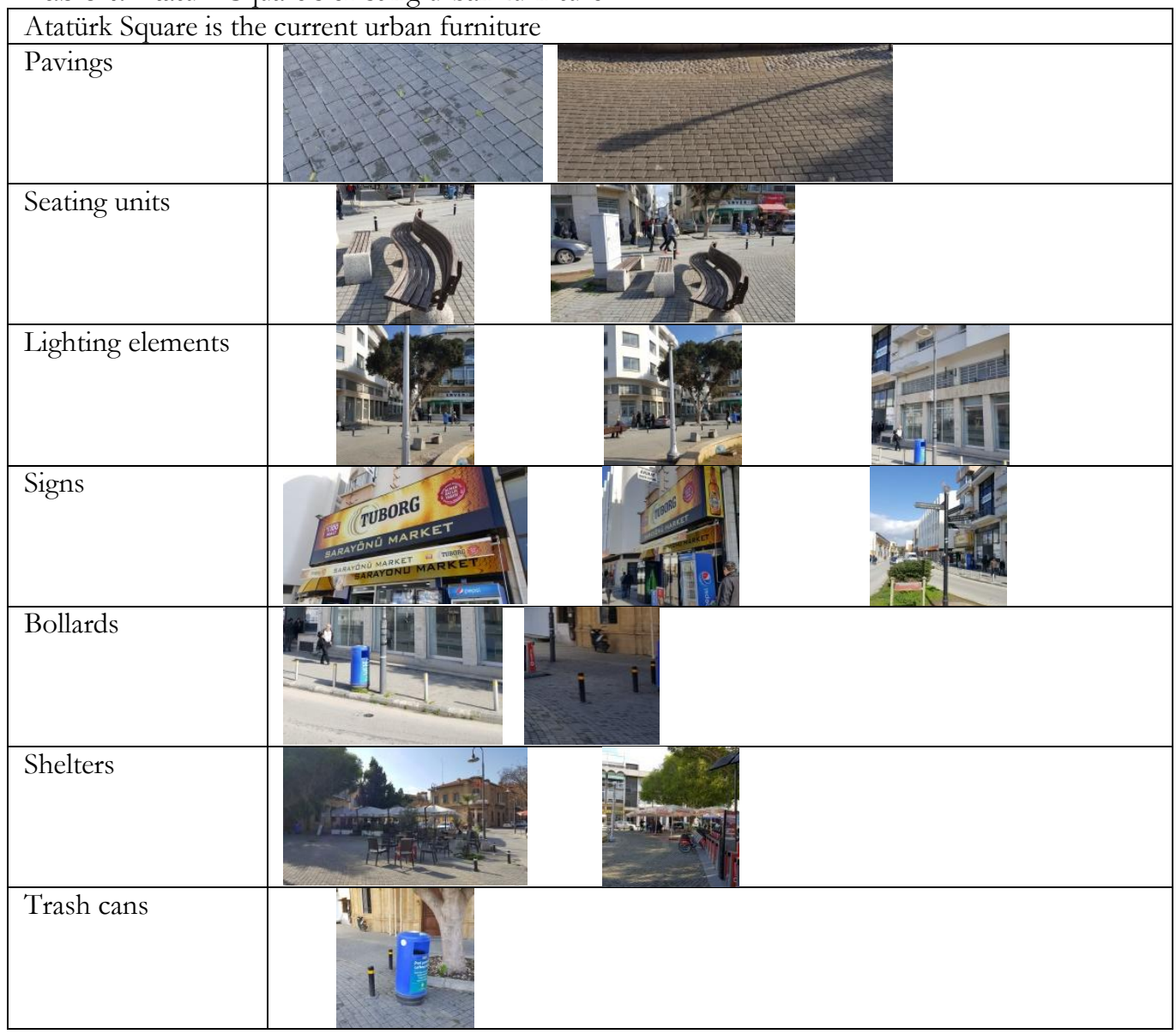




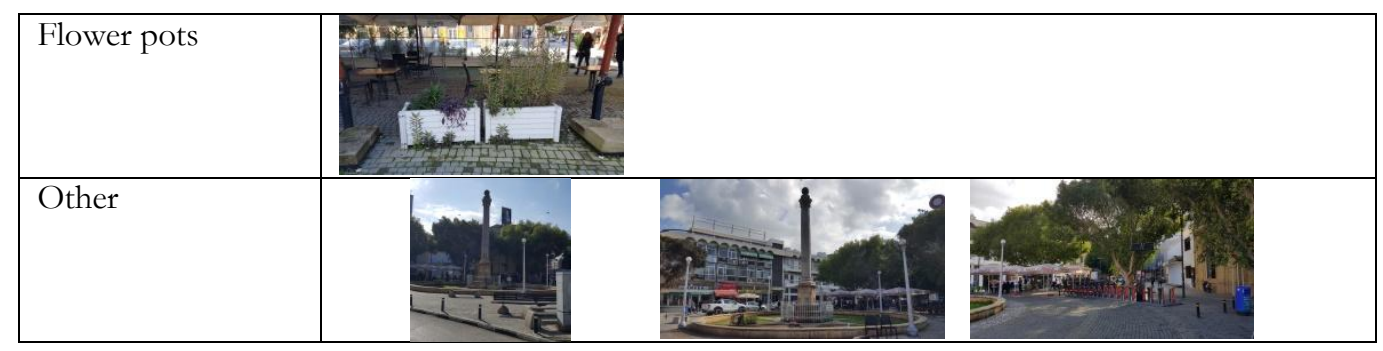

It was observed that shelters, pavings, seating units, signs and information boards in the Arasta Square and Lokmaci Barricade were in harmony with the surrounding environment but trash cans, lighting elements and flower pots were inadequate (See Table 5).

Table 5. Existing urban furniture at Arasta Square and Lokmac1 Barricade

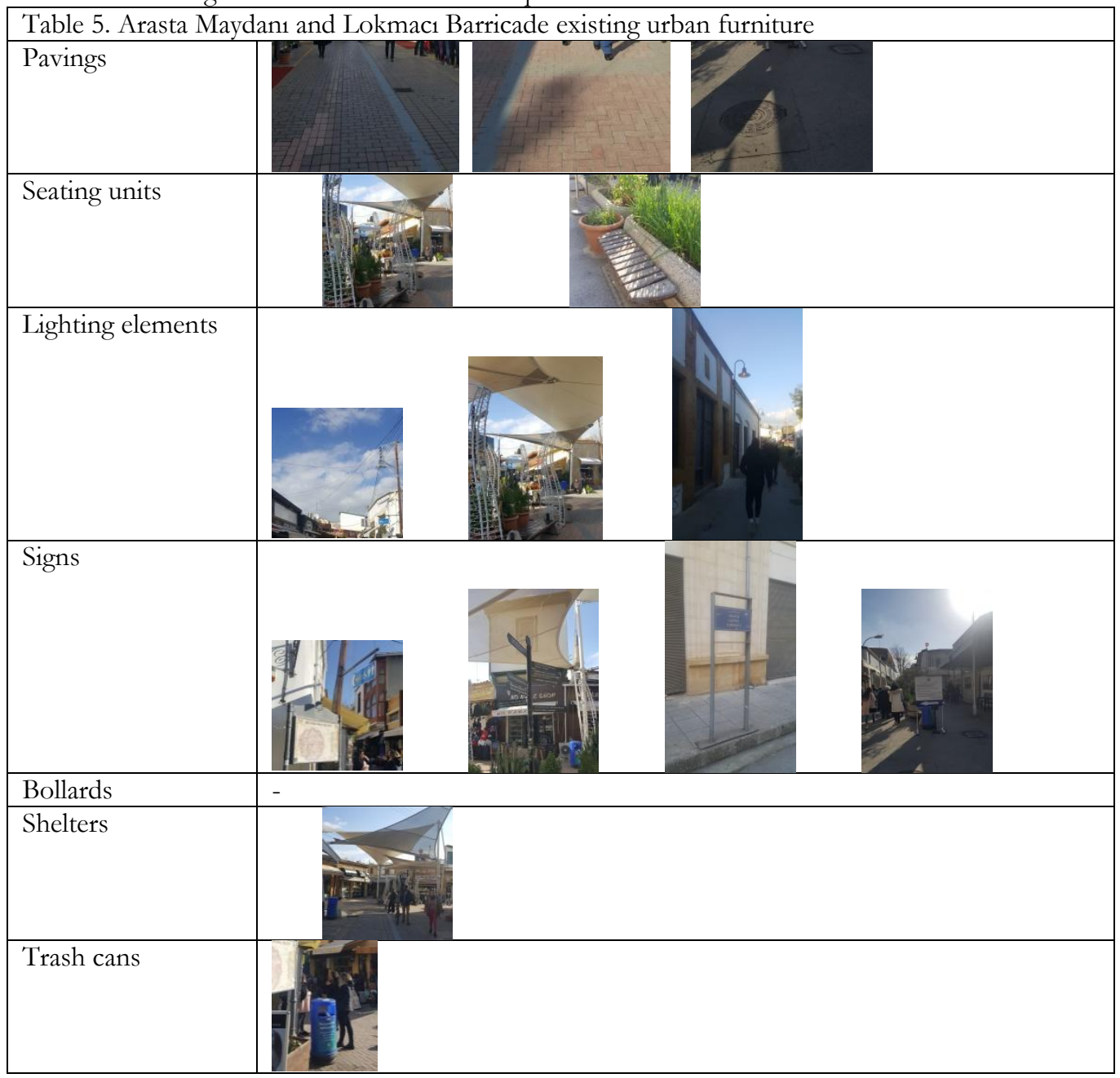




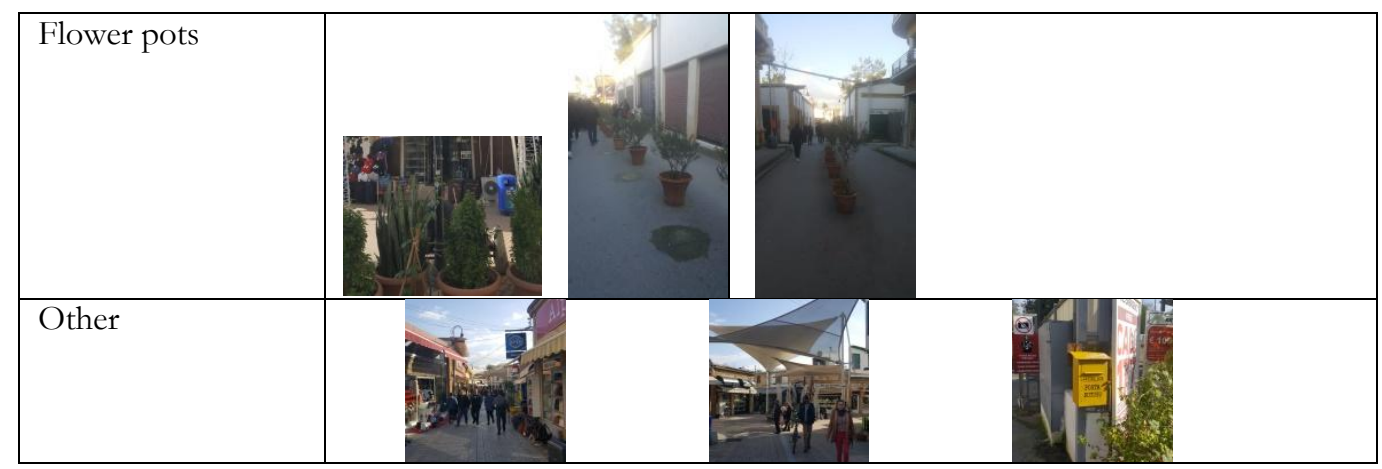

\subsection{Analysis of the existing urban furniture at the South Nicosia Old City}

It has been observed that the urban furniture elements in Ledra Street on the same axis in the south of Nicosia Old City, were more compatible with the environment, more functional and newer than the ones used on the North side (See Table 6). Seating elements, trash cans, flower pots and lighting elements along the street have provided a unity and the paving is in harmony with the environment. In addition, the cover elements used for shading create a more comfortable environment for users. On the north side, no mail boxes are used, whereas the mail boxes used on Ledra Street adapt to the environment as urban furniture.

Table 6. The existing urban furniture at Ledra Street

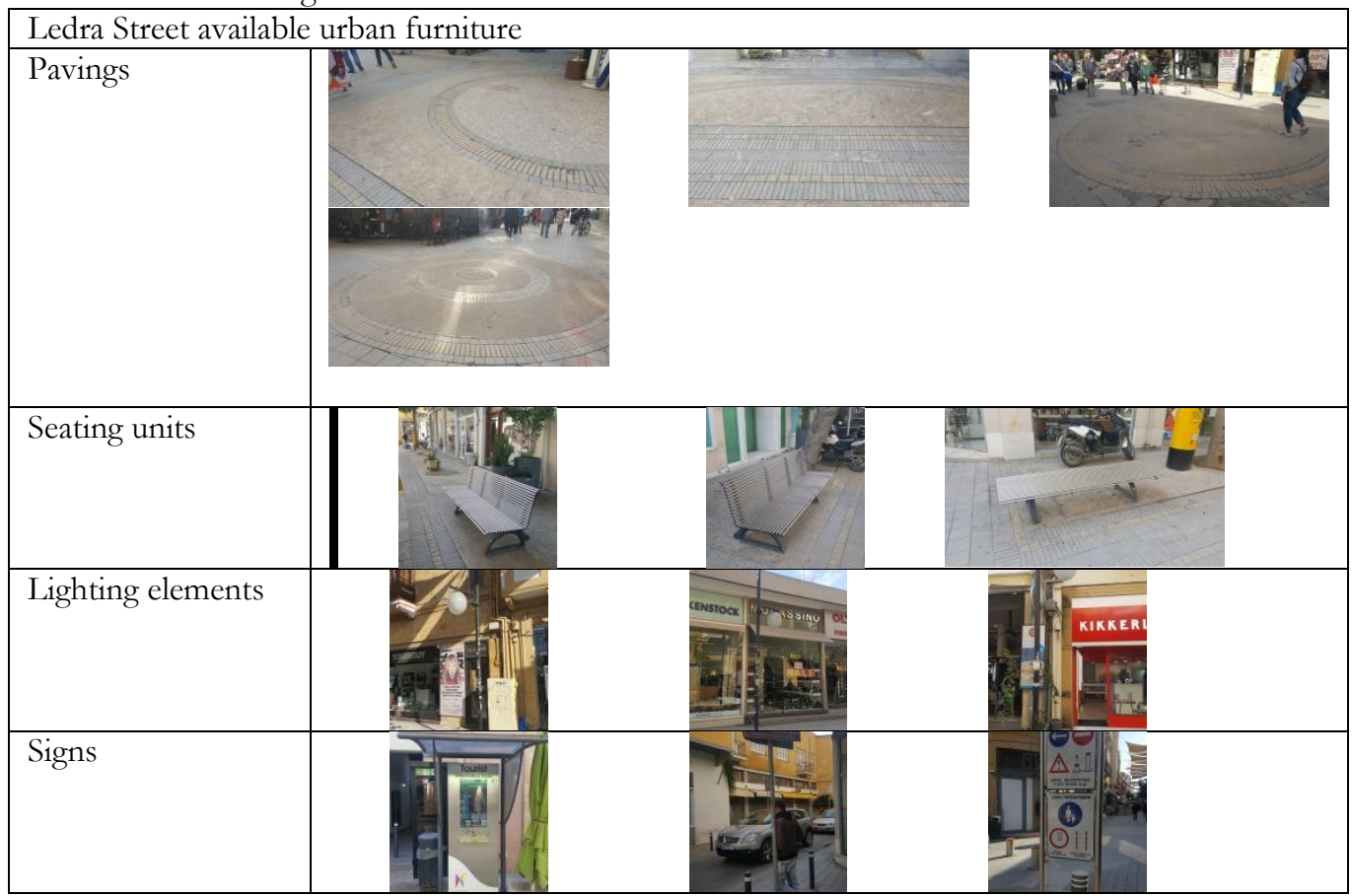




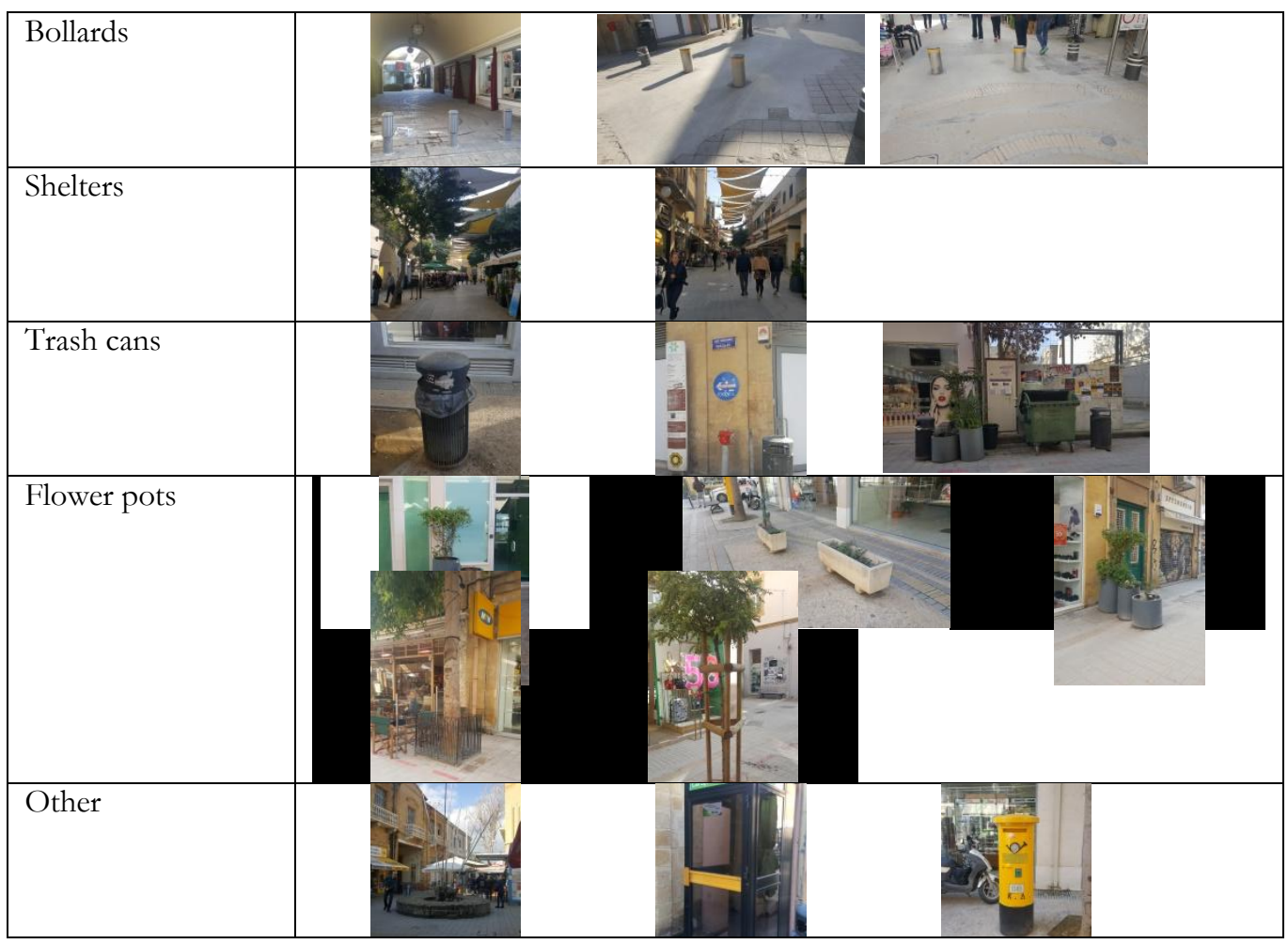

In the Eleftherias Square at the end of Ledra Street, it was found that flower pots, seating items, trash cans and barriers were used in a more functional and environmentally compatible way than the Atatürk and Inönü Square on the North. In addition, it is observed that the new style, modern and more functional materials are used in the area, which is pedestrianized as an extension of this square. These urban firniture elements used attract attention (Table 7).

Table 7. Eleftherias Square's existing urban furniture

\begin{tabular}{|l|c|c|}
\hline Eleftherias Square existing urban furniture & \\
\hline Pavings & & \\
\hline Seating units & & \\
\hline Lighting elements & & \\
\hline
\end{tabular}




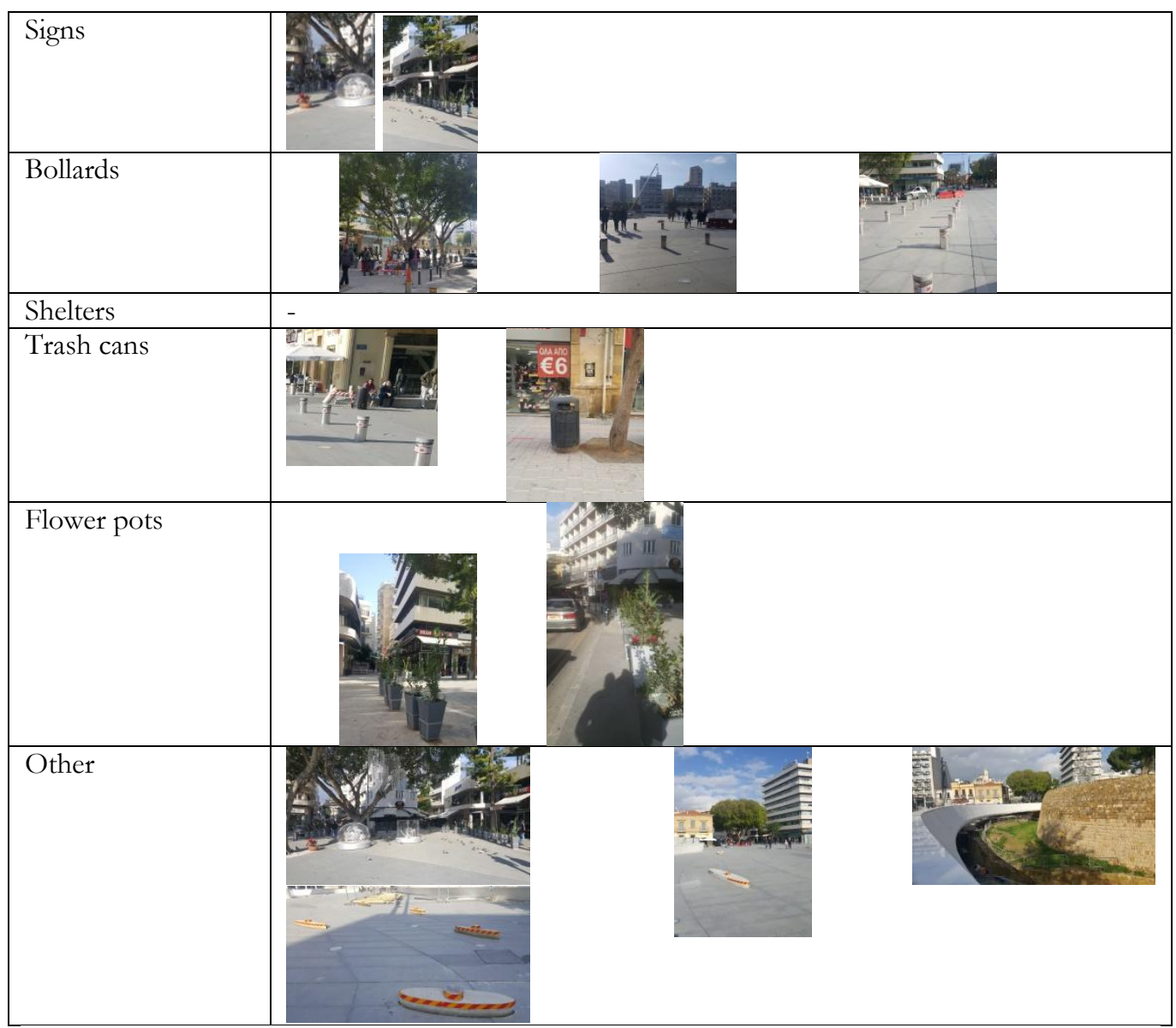

\section{Conclusion And Discussion}

The elements that make up the identity of a city need to be correctly identified and defined. In determining the identity of the city formed as a result of the interrelation of natural environment, socio-cultural structure and the built environment, it must be considered and evaluated as a whole (Önem ve Kılınçarslan, 2005).

Urban furniture symbolizes and represents the city where it is located. In addition, these elements have a meaning and value over time, depending on their functional use as well as the lifestyle of society. Therefore, these urban furniture elements contribute to the urban identity.

As the research area, the city of Nicosia has become a center of interest in recent years for both tourists and the locals, because of increasing conservation and renovation activities in its historical texture. However, as a result of the research conducted, it has been observed that the existing urban furniture elements in the region do not have any characteristic to emphasize the identity of the city. In the streets and squares on the North side, it was observed that urban furniture was qualitatively and quantitatively 
insufficient in general and did not provide a unity with the surrounding built environment. However when designing urban furniture elements within the historical sites, they should be designed to reflect the urban identity. In this context, when the study area is examined, it is determined that the urban furniture elements used in squares and streets do not form an integrity with the architectural structure.

The fact that there are pedestrianized areas within the research area and that public transportation is limited, users visit this area by walking. However, it was observed that the streets and squares on the north side were inadequate, not functional and not ergonomic for pedestrians in terms of urban furniture equipments. It has been observed that the floor coverings, seating elements, lighting elements, signs, flower pots, barriers and shelters are insufficient. On the other hand, it has been found that these equipments on the South side are more environmentally friendly, adequate and more functional.

For this reason, due to the fact that the area is a city center and a historical environment, urban furniture should be more functional and aesthetic in the Walled City of Nicosia on the north side. As concluding remarks it can be argued that, not only the urban furniture but also the urban open and green spaces should be emphasized and should be given importance in all scales of urban environments, including the historical contexts, as a must of sustainable urbanization as a multidimensional concept.

\section{References}

Ahunbay, Z. (Nisan 1996). Taribi Cevre Koruma ve Restorasyon. İstanbul: Yap1 Endüstri Merkezi.

Aksu, Ö. V. (2012). Kent Mobilyaları Tasarımında Özgün Yaklaşımlar. Inönü Üniversitesi Sanat ve Tasarm Dergisi, 2(6) , 373-386.

Altan, Z. (2016). Gižemli Kıbrıs. Lefkoşa: Okman Printing.

Arbolino, R., Carlucci, F., Simone, L., Yigitcanlar, T., \& Ioppolo, G. (2018). The policy diffusion of environmental performance in the European countries. Ecological Indicators, 89, 130-138.

Asilsoy, B., A survey study on environmental consciousness in Famagusta, Asia Pacific International Conference on Environment Behaviour Studies (AicE-BSc 2011), 7-9 December 2011, Famagusta, North Cyprus.

Asilsoy, B., Laleci S., Yıldırım S., Uzunoğlu K., Fuller Ö. (2017). Environmental Awareness and Knowledge among Architecture Students in North Cyprus, International Journal of Educational Sciences, 19 (2-3), pp. 136-143.

Asilsoy B., \& Oktay D. (2018). Exploring environmental behaviour as the major determinant of ecological citizenship, Sustainable Cities and Society, Volume 39C, 765-771.

Bayrakçı, O. (1989). Kent Mobilyaları Tasarımında Kimlik Sorunu ve Kent Kimliği İçindeki Yeri Yayını. Kamu Mekanlar Tasarmi ve Kent Mobilyalar Sempozyumu, (s. 75-77).

Bayramoğlu, E., \& Özdemir, B. (2011). Trabzon Kent Kimliği, Uzun Sokak Kentsel Donatı Elemanlarının Kent Kimliği Açısından Değerlendirilmesi. Kastamonu Üniversitesi Orman Fakültesi Dergisi(12 (2)), 182-191.

Beyaz, C., \& Asilsoy, B. (2019). Knowledge of green buildings and environmental worldview among interior design students. INTERNATIONAL JOURNAL OF ADVANCED AND APPLIED SCIENCES, 6(1), 29-36.

Bingöl, B. (2017). Kent Mobilyalarının Kentsel Mekanlarda Kent Kimliği ile İlişkilendirilmesi: Isparta Kaymak Kap1 Meydanı Örneği. İleri Teknoloji Bilimleri Dergisi, 193-202.

Bolkaner, M. K. (2018). Tarihi Çevre Yenileme ve Kentsel Tasarım Çalışmalarının Lefkoşa Suriçi Örneğinde Kent Kullanıcıları Açısından Araştırılması. Yüksek Lisans Tez̨i. Lefkoşa: Yakın Doğu Üniversitesi.

Bulut, Y., Atabeyoğlu, Ö., \& Yeşil, P. (2008). Erzurum Kent Merkezi Donatı Elemanlarının Ergonomik Özelliklerinin Değerlendirilmesi Üzerine Bir Araştırma. Tarm Bilimleri Dergisi(14(2)), 131-138.

Conteh, F. M., Oktay, D. (2016). Measuring Liveability by Exploring Urban Qualities of Kissy Street, Freetown, Sierra Leone. Open House Inetrnational, Vol 41, No:2, 23-30. 
Ertaş, Ş. (2017). Tarihi Çevre İçinde Kent Mobilyaları Tasarıma Yönelik Bir Yötem Önerisi: Konya Sille. Mebmet Akif Ersoy Üniversitesi Fen Bilimleri Enstitüsü Dergisi(8 (1)), 78-95.

Ewing, R., Hajrasouliha, A., Neckerman, K. M., Purciel-Hill, M., \& Greene, W. (2015). Streetscape features related to pedestrian activity. Journal of Planning Education and Research, 36 (1), 5-15. http://dx.doi.org/10.1177/0739456x15591585

Faragallah, R. N. (2018). The impact of productive open spaces on urban sustainability: The case of El Mansheya Square-Alexandria. Alexandria engineering journal, 57(4), 3969-3976.

Ghorab, P., \& Yücel Caymaz, G. (2015). Evaluation of Street Furniture According to Basic Design Principles. International Journal of Electronics, Mechanical and Mechatronics Engineering(4(3)), 757-772.

Gürkan, H. (1996). Dünkü ve Bügünkü Lefkoşa Toplu Eserler 3. Lefkoşa: Galeri Kültür Yayınlar1.

Kamruzzaman M., Deilami K., Yigitcanlar T. (2018). Investigating the urban heat island effect of transitoriented development in Brisbane Journal of Transport Geography, 66, pp. 116-124.

Kibris.com.tr. (2018). Kuzey Kıbris Haritalar, Kıbris Karayollar Haritası. 2018 tarihinde Kibris.com.tr: https://kibris.com.tr/images/haritalar/kibris_karayollari_haritasi.jpg adresinden alındı

Marquez-Ballesteros M-J., Mora-López L., Lloret-Gallego P., Sumper A., Sidrach-de-Cardona M. (2019). Measuring urban energy sustainability and its application to two Spanish cities: Malaga and Barcelona, Sustainable Cities and Society, Vol 45, pp. 335-347.

Oktay, D. (2002). The quest for urban identity in the changing context of the city: Northern Cyprus. Cities, 19(4), 261-271.

Önem, A., \& Kılınçarslan, İ. (2005). Haliç Bölgesinde Çevre Algılama ve Kentsel Kimlik. İTÜ Dergisi/A, Mimarlk, Planlama ve Tasarm(4(1)), 115-225.

Salama, A., \& Azzali, S. (2015). Examining attributes of urban open spaces in Doha. Proceedings of the ICEUrban Design and Planning, 168(2), 75-87.

S..Çöl. (1998). 12019 tarihinde Kent ve Mimarlık: http://www.solencol.com/b10.htm adresinden alındı

Şatır, S., \& Korkmaz, E. (2005). Urban Open Spaces With Examples \& The Classification of Urban Furniture. İTÜ $A / Z(2), 130-141$.

Turkan, Z., \& Özburak, Ç. (2018). Lefkoșa Tarihi Kent Dokusunda "Selimiye Meydanı"/"Selimiye Square" Within the Historical City Texture of Nicosia. Journal of History Culture and Art Research, 7(2), 430443. 